\title{
Pertumbuhan dan Produksi Kacang Bogor (Vigna subterranea (L.) Verdcourt) pada Beberapa Jarak Tanam dan Frekuensi Pembumbunan
}

\section{Growth and Yield of Bambara Groundnut (Vigna subterranea (L.) Verdcourt) in Several Plant Spacings and Ridging Frequencies}

\author{
Aulia Rahmawati $^{1 *}$, Heni Purnamawati ${ }^{1}$, Yudiwanti W. E. Kusumo ${ }^{1}$ \\ ${ }^{1}$ Departemen Agronomi dan Hortikultura,Fakultas Pertanian, Institut Pertanian Bogor \\ (Bogor Agricultural University), Jl. Meranti, Kampus IPB Darmaga, Bogor 16680, Indonesia \\ Telp. \& Faks. 62-251-8629353 e-mail agronipb@indo.net.id \\ *Penulis untuk korespondensi: rahmawati.aulia91@gmail.com
}

Disetujui 14 November 2016 / Published online 8 Desember 2016

\begin{abstract}
This research aimed to get optimal plant spacing and proper frequency in ridging to produce the best yields. This research was conducted in randomized complete block design factorial with two factors and three replications. The first factor is plant spacing which consist of six levels: $40 \mathrm{~cm} \times 25 \mathrm{~cm}, 50 \mathrm{~cm} \times 25 \mathrm{~cm}$, $60 \mathrm{~cm} \times 25 \mathrm{~cm}, 40 \mathrm{~cm} \times 40 \mathrm{~cm}, 50 \mathrm{~cm} \times 50 \mathrm{~cm}$, and $60 \mathrm{~cm} \times 60 \mathrm{~cm}$. The second factor is ridging frequencies which consist of two levels: twice and three times ridging. The result of this research showed that plant spacing effected significantly the number of leaves, canopy width, leaf area index, plant dry weight per plant, pods wet weight per plant, pods dry weight per plant, seed weight per plant, number of filled pods per plant, number of harvested plant, pods wet weight plot, pods dry weight plot, and seed weight plot, whereas ridging frequency only effected significantly on plant dry weight per plant. Plant spacing $60 \mathrm{~cm} x 25 \mathrm{~cm}$ and $40 \mathrm{~cm} x$ $40 \mathrm{~cm}$ produced the best yields and suitable for use in plant cultivation.
\end{abstract}

Keywords: bambara groundnut, plant spacing, ridging

\section{ABSTRAK}

Penelitian ini bertujuan untuk mendapatkan jarak tanam yang optimal dan frekuensi pembumbunan yang tepat untuk mendapatkan hasil panen terbaik. Penelitian ini menggunakan rancangan kelompok lengkap teracak (RKLT) faktorial dengan dua faktor dan tiga ulangan. Faktor pertama adalah jarak tanam yang terdiri atas enam taraf, yaitu $40 \mathrm{~cm} \times 25 \mathrm{~cm}, 50 \mathrm{~cm} \times 25 \mathrm{~cm}, 60$ $\mathrm{cm} \times 25 \mathrm{~cm}, 40 \mathrm{~cm} \times 40 \mathrm{~cm}, 50 \mathrm{~cm} \times 50 \mathrm{~cm}$, dan $60 \mathrm{~cm} \times 60 \mathrm{~cm}$. Faktor kedua adalah frekuensi pembumbunan yang terdiri dari dua taraf yaitu dua kali pembumbunan dan tiga kali pembumbunan. Hasil penelitian menunjukkan jarak tanam berpengaruh nyata terhadap peubah jumlah daun, lebar kanopi, indeks luas daun (ILD), bobot brangkasan kering per tanaman, bobot polong basah per tanaman, bobot polong kering per tanaman, bobot biji per tanaman, jumlah polong bernas per tanaman, jumlah tanaman yang dipanen, bobot polong basah petak, bobot polong kering petak, dan bobot biji petak, sedangkan frekuensi pembumbunan hanya berpengaruh pada bobot brangkasan kering per tanaman. Jarak tanam $60 \mathrm{~cm} \times 25 \mathrm{~cm}$ dan $40 \mathrm{~cm} \times 40 \mathrm{~cm}$ memberikan hasil panen terbaik dan sesuai digunakan dalam budidaya kacang bogor.

Kata kunci: jarak tanam, kacang bogor, pembumbunan 


\section{PENDAHULUAN}

Vigna subterranea (L.) Verdcourt atau yang lebih dikenal dengan kacang bogor kurang dikenal di pasaran Indonesia, tetapi kacang jenis ini sudah sangat dikenal oleh masyarakat Afrika. Menurut Deshpande and Damodaran (1990) kacang bogor ini bisa dikonsumsi saat masih muda atau pun saat telah matang. Biji yang masih muda biasa dikonsumsi segar atau dipanggang. Biji dapat direbus dalam keadaan muda dan masih hijau baik dengan atau tanpa cangkangnya. Biji dari kacang bogor memiliki kandungan gizi yang lengkap karena mengandung protein, karbohidrat, dan lemak dengan proporsi yang cukup untuk menyediakan makanan yang bernutrisi. Studi oleh Amarteifio and Maholoo (1998) melaporkan bahwa kacang bogor mengandung $11.4 \%$ protein, $53.1 \%$ karbohidrat, $6.1 \%$ lemak, $6.1 \%$ serat, $0.097 \%$ kalsium, $0.007 \%$ zat besi, $1.2 \%$ kalium, dan $0.003 \%$ sodium.

Hasil biji kering tertinggi pada kondisi lapang yang pernah tercatat yaitu 4 ton/ha. Ratarata biji kering yang dihasilkan berkisar antara $300-800 \mathrm{~kg} / \mathrm{ha}$, namun panen yang kurang dari $100 \mathrm{~kg} / \mathrm{ha}$ pun banyak ditemukan (Brink et al., 2006). Hasil panen $300-800 \mathrm{~kg} / \mathrm{ha}$ biasa ditemukan di budidaya tradisional dan bisa mencapai 3 ton/ha pada budidaya yang intensif (Baudoin and Mergeai, 2001). Praktek budidaya intensif perlu dilakukan agar hasil panen tanaman dapat ditingkatkan, salah satunya dengan pengaturan kerapatan tanam. Peningkatan kerapatan tanaman sampai batas tertentu dapat meningkatkan produksi setiap satuan luas, tetapi selanjutnya produksi akan menurun sejalan oleh meningkatnya persaingan tanaman (Turmudi et al., 1996). Tanaman yang ditanam rapat akan memperbesar kemungkinan terjadinya kompetisi antar tanaman sejenis dan kompetisi dengan gulma. Kompetisi tersebut dapat mempengaruhi hasil dari tanaman pokok. Menurut Hasanuddin et al., (1999), hal inilah yang menyebabkan diperlukannya jarak tanam optimal untuk menentukan kerapatan tanaman yang memberikan hasil yang paling baik. Turmudi dan Suprijono (2004) menyatakan bahwa pengaturan jarak tanam optimal pada setiap komoditas dapat mengurangi ruang gerak pertumbuhan gulma.

Tanaman kacang bogor memiliki bunga yang tumbuh di atas permukaan tanah dan akan terus terbentuk sampai tanaman mati. Saat polong terbentuk perlu dilakukan pembumbunan agar kualitas polong yang terbentuk baik dan tidak berwarna hijau. Pembumbunan dilakukan untuk menutup polong-polong muda yang tumbuh. Pembumbunan dapat dilakukan secara manual maupun menggunakan alat bantu. Kegiatan ini dapat meningkatkan hasil panen, tapi membutuhkan banyak tenaga kerja (Brink et al., 2006). Menurut Purseglove (1992) pembumbunan biasanya dilakukan pada baris tanaman dan di beberapa tempat dilakukan untuk mendukung produksi polong. Curah hujan yang tinggi dapat mengakibatkan erosi tanah sehingga menjadikan polong tidak tertutup tanah. Curah hujan di Bogor cukup tinggi, oleh karena itu, frekuensi pembumbunan menjadi penting dipelajari. Penelitian ini bertujuan untuk mendapatkan jarak tanam yang optimal dan frekuensi pembumbunan yang tepat untuk mendapatkan hasil panen terbaik

\section{BAHAN DAN METODE}

Percobaan dilaksanakan di Kebun Percobaan Cikabayan IPB Dramaga, Bogor, Jawa Barat dengan jenis tanah latosol. Percobaan dilaksanakan dari bulan Maret sampai dengan Juli 2013. Bahan yang digunakan antara lain: benih lanras kacang bogor yang berasal dari Desa Cipicung, Kabupaten Sumedang, pupuk kandang kambing, pupuk NPK (15:15:15), fungisida berbahan aktif propineb, insektisida berbahan aktif profonofos dan insektisida berbahan aktif karbofuran. Alat-alat yang digunakan terdiri atas alat budidaya pertanian, leaf area meter LI3000C, timbangan analitik, label percobaan, ajir contoh dan alat tulis.

Penelitian ini disusun menggunakan rancangan kelompok lengkap teracak (RKLT) faktorial dengan dua faktor dan tiga ulangan. Faktor pertama yaitu jarak tanam yang terdiri dari enam taraf, yaitu: $40 \mathrm{~cm} \times 25 \mathrm{~cm}, 50 \mathrm{~cm} \times 25 \mathrm{~cm}$, $60 \mathrm{~cm} \times 25 \mathrm{~cm}, 40 \mathrm{~cm} \times 40 \mathrm{~cm}, 50 \mathrm{~cm} \times 50 \mathrm{~cm}$, dan $60 \mathrm{~cm}$ x $60 \mathrm{~cm}$. Faktor kedua yaitu frekuensi pembumbunan yang memiliki dua taraf, yaitu: pembumbunan dilakukan 2 kali pada 8 dan 10 minggu setelah tanam (MST), dan pembumbunan dilakukan 3 kali pada 8, 10, dan 12 MST. Percobaan ini memiliki 12 kombinasi perlakuan. Setiap perlakuan diulang sebanyak tiga kali, sehingga percobaan ini memiliki 36 satuan percobaan. Setiap satuan percobaan diamati lima tanaman contoh, sehingga jumlah seluruh tanaman contoh adalah 180 tanaman. Pengaruh dari seluruh perlakuan dapat diketahui dengan menggunakan uji $\mathrm{F}$ pada taraf $5 \%$. Apabila terdapat pengaruh nyata terhadap parameter yang diamati maka setiap perlakuan dibandingkan dengan menggunakan uji BNT pada taraf 5\%.

Unit percobaan berukuran $3 \mathrm{~m} \times 2.5 \mathrm{~m}$ dan diberi pupuk kandang kambing dengan dosis 2 ton $\mathrm{ha}^{-1}$ diberikan saat pengolahan tanah. Penanaman dilakukan dengan jarak tanam sesuai 
perlakuan dengan satu benih per lubang tanam. Insektisida berbahan aktif karbofuran dengan dosis $15 \mathrm{~kg} \mathrm{ha}^{-1}$ diberikan saat benih ditanam. Pupuk yang diberikan yaitu NPK (15:15:15) dengan dosis $200 \mathrm{~kg} \mathrm{ha}^{-1}$ pada 2 MST. Penyulaman dilakukan pada umur 2 MST. Pemeliharaan yang dilakukan meliputi penyiangan gulma sekaligus dilakukan untuk menggemburkan tanah. Penyiangan gulma dilakukan sebanyak tiga kali bersamaan dengan dilakukannya pembumbunan. Penyiraman pada tanaman dilaksanakan jika tidak terjadi hujan dalam satu minggu. Pembumbunan dilakukan sesuai perlakuan. Penyemprotan terhadap hama dan penyakit dilakukan dengan fungisida berbahan aktif propineb dengan dosis $1.5 \mathrm{~g} \mathrm{Liter}^{-1}$ dan insektisida berbahan aktif profonofos dengan dosis $4 \mathrm{cc} \mathrm{Liter}^{-1}$. Penyemprotan dilakukan mulai tanaman berumur 4 minggu setelah tanam (MST) sebanyak empat kali, satu kali per minggu. Panen kacang bogor dilakukan pada 17 MST, saat $80 \%$ daun menguning atau mengering.

Pengamatan fase vegetatif dilakukan pada 4-12 MST. Peubah yang diamati yaitu jumlah daun, lebar kanopi, dan indeks luas daun. Pengamatan fase generatif terdiri dari beberapa peubah yaitu bobot brangkasan kering per tanaman (BBK), bobot polong basah per tanaman (BPB), bobot polong kering per tanaman (BPK), bobot bij per tanaman (BBJ), jumlah polong bernas per tanaman (JPB), jumlah polong hijau (JPH) per tanaman, jumlah polong cipo (JPC) per tanaman, indeks panen (IP), jumlah tanaman yang dipanen, bobot polong basah petak, bobot polong kering petak, dan bobot biji petak.

\section{HASIL DAN PEMBAHASAN}

\section{Kondisi Umum}

Secara keseluruhan kondisi pertanaman kacang bogor saat penelitian cukup baik, namun struktur tanah pada saat penanaman masih berupa bongkahan-bongkahan karena hari-hari sebelumnya belum turun hujan. Pada awal pertanaman cuaca cukup kering, sehingga beberapa kali dilakukan penyiraman untuk memenuhi kebutuhan air tanaman. Hal ini merupakan kendala yang cukup berat di awal penelitian. Benih yang baru ditanam perlu air yang cukup agar dapat segera berkecambah.

Tanaman kacang bogor berkecambah pada 10-14 hari setelah tanam (HST). Benih berkecambah tidak dalam waktu yang bersamaan. Hal ini diduga karena benih yang digunakan merupakan benih varietas lokal. Persentase daya tumbuh yang dihitung pada 2 MST memiliki ratarata sebesar $58.53 \%$. Selanjutnya dilakukan penyulaman. Penyulaman dilakukan untuk menggantikan benih yang tidak hidup saat ditanam, sehingga jumlah tanaman yang dipanen tidak terlalu sedikit. Jumlah tanaman yang dipanen mempengaruhi bobot polong total yang dipanen. Tabel 1 memperlihatkan jumlah tanaman kacang bogor yang dipanen pada setiap petak perlakuan. Hampir semua petak memiliki rata-rata jumlah tanaman yang dipanen lebih tinggi dibandingkan persentase daya tumbuh sebelum dilakukan penyulaman.

Tabel 1. Jumlah tanaman kacang bogor yang dipanen per petak

\begin{tabular}{lcccc}
\hline Jarak tanam & Ulangan 1 & Ulangan 2 & Ulangan 3 & Rata-rata \\
\hline $40 \mathrm{~cm} \times 25 \mathrm{~cm}$ & $47(62.67 \%)$ & $26(34.67 \%)$ & $38(50.67 \%)$ & $37(49.34 \%)$ \\
$50 \mathrm{~cm} \times 25 \mathrm{~cm}$ & $45(75.00 \%)$ & $30(50.00 \%)$ & $38(63.33 \%)$ & $38(62.78 \%)$ \\
$60 \mathrm{~cm} \times 25 \mathrm{~cm}$ & $33(66.00 \%)$ & $31(62.00 \%)$ & $26(52.00 \%)$ & $30(60.00 \%)$ \\
$40 \mathrm{~cm} \times 40 \mathrm{~cm}$ & $32(68.09 \%)$ & $23(48.93 \%)$ & $32(68.09 \%)$ & $29(61.70 \%)$ \\
$50 \mathrm{~cm} \times 50 \mathrm{~cm}$ & $28(93.33 \%)$ & $16(53.33 \%)$ & $19(63.33 \%)$ & $21(69.99 \%)$ \\
$60 \mathrm{~cm} \times 60 \mathrm{~cm}$ & $16(76.19 \%)$ & $14(66.67 \%)$ & $13(61.90 \%)$ & $14(68.25 \%)$ \\
\hline
\end{tabular}

Penyulaman dilakukan pada 14 HST. Penyemprotan menggunakan fungisida berbahan aktif propineb dengan dosis $1.5 \mathrm{~g} \mathrm{~L} \mathrm{~L}^{-1}$ dan insektisida berbahan aktif profonofos dengan dosis $4 \mathrm{cc} \mathrm{L}^{-1}$. Penyemprotan dilakukan mulai tanaman berumur 4 minggu setelah tanam (MST) sebanyak empat kali, satu kali per minggu. Penyemprotan dilakukan pada hari cerah agar efektif.

Benih yang tidak tumbuh ada yang disebabkan dimakan oleh serangga dan juga ada yang terserang cendawan. Benih yang tidak tumbuh karena dimakan serangga akan menyisakan kulit biji di tanah, sedangkan benih yang tidak tumbuh karena cendawan akan tampak membusuk dan terselubungi oleh hifa cendawan. Tanaman yang terserang penyakit kerdil ditemukan pada pertanaman kacang bogor pada 7 MST. Terdapat lima tanaman yang terserang penyakit kerdil dari seluruh tanaman yang ada. Penyakit ini menyebabkan tanaman tumbuh secara abnormal dengan ukuran daun mengecil dan mengeriting. Tanaman yang terserang penyakit ini harus segera dicabut karena jika tidak 
dapat menular pada tanaman yang lain. Selain itu terdapat beberapa hama yang menyerang tanaman kacang bogor. Hama tersebut adalah Valanga nigricornis yang menyerang bagian daun tanaman.

Gulma yang tumbuh di sekitar pertanaman berkompetisi untuk mendapatkan unsur hara yang diperlukan. Penyiangan gulma pada budidaya kacang bogor sangat perlu untuk dilakukan untuk mendapatkan produksi yang baik. Ridwan et al., (1997) juga menyatakan bahwa penyiangan manual membuat tanah menjadi gembur, sehingga pertumbuhan tanaman subur dan pembentukan cabang sempurna. Penyiangan gulma dilakukan secara manual sebanyak 3 kali yaitu pada 5, 8, dan 12 MST. Penyiangan gulma dilakukan bersamaan dengan pembumbunan.

Tanaman kacang bogor memasuki fase generatif pada umur 6 MST dan $70 \%$ populasi tanaman berbunga pada 7 MST. Tanaman dipanen pada umur 17 MST. Tanaman yang siap panen ditunjukkan dengan warna daun yang sudah $80 \%$ menguning dan polong tidak lagi berwarna putih.

\section{Fase Vegetatif}

Peubah yang diamati pada fase vegetatif, yaitu jumlah daun, lebar kanopi, dan indeks luas daun (ILD). Peubah jumlah daun dan lebar kanopi diamati pada 4 - 12 MST dengan frekuensi pengamatan dua kali seminggu. Peubah indeks luas daun diamati pada 5 MST.

Jumlah daun. Daun merupakan salah satu tempat proses fotosintesis berlangsung. Fotosintesis akan menghasilkan karbohidrat yang pada fase generatif digunakan lebih banyak untuk pembentukan dan pengisian polong. Karena itu semakin banyak daun yang dimiliki tanaman akan semakin banyak pula karbohidrat yang digunakan untuk pembentukan dan pengisian polong. Atifach (1992) juga menyatakan hal yang selaras yaitu jumlah daun berkorelasi nyata dan positif terhadap hasil, ini berarti semakin banyak jumlah daun yang dihasilkan akan semakin meningkatkan hasil.

Tabel 2 terlihat bahwa perlakuan jarak tanam berpengaruh nyata pada peubah jumlah daun pada 4, 10 dan 12 MST. Pada awal fase pertumbuhan terlihat bahwa tanaman dengan jarak tanam $40 \mathrm{~cm} \times 25 \mathrm{~cm}, 50 \mathrm{~cm} \times 25 \mathrm{~cm}$, dan $60 \mathrm{~cm}$ x $25 \mathrm{~cm}$ memiliki jumlah daun nyata lebih banyak daripada jarak tanam lain, akan tetapi pada minggu-minggu selanjutnya jarak tanam yang lebar yaitu $60 \mathrm{~cm} \times 60 \mathrm{~cm}$ dan $50 \mathrm{~cm} \times 50 \mathrm{~cm}$ memiliki jumlah daun nyata lebih banyak daripada jarak tanam lain. Hal ini dikarenakan tanaman yang berjarak tanam $60 \mathrm{~cm}$ x $60 \mathrm{~cm}$ dan $50 \mathrm{~cm} \times 50 \mathrm{~cm}$ memiliki persaingan faktor tumbuh yang lebih kecil dibandingkan dengan tanaman dengan jarak tanam yang rapat.

Tabel 2. Jumlah daun kacang bogor pada beberapa jarak tanam dan frekuensi pembumbunan

\begin{tabular}{|c|c|c|c|c|c|}
\hline \multirow{2}{*}{ Perlakuan } & \multicolumn{5}{|c|}{ Umur tanaman (MST) } \\
\hline & 4 MST & $6 \mathrm{MST}$ & $8 \mathrm{MST}$ & $10 \mathrm{MST}$ & 12 MST \\
\hline Jarak tanam & \multicolumn{5}{|c|}{ 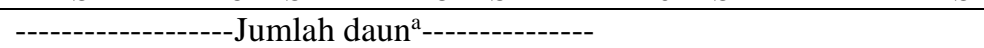 } \\
\hline $40 \mathrm{~cm} \times 25 \mathrm{~cm}$ & $8.80 \mathrm{ab}$ & 22.33 & 50.69 & $53.33 \mathrm{c}$ & $58.17 \mathrm{~b}$ \\
\hline $50 \mathrm{~cm} \times 25 \mathrm{~cm}$ & $8.73 \mathrm{ab}$ & 21.90 & 38.94 & $53.23 \mathrm{c}$ & $57.00 \mathrm{~b}$ \\
\hline $60 \mathrm{~cm} \times 25 \mathrm{~cm}$ & $9.60 \mathrm{a}$ & 23.66 & 37.27 & $52.77 \mathrm{c}$ & $57.03 \mathrm{~b}$ \\
\hline $40 \mathrm{~cm} \mathrm{x} 40 \mathrm{~cm}$ & $7.70 \mathrm{~b}$ & 20.47 & 39.63 & $56.00 \mathrm{bc}$ & $58.83 \mathrm{~b}$ \\
\hline $50 \mathrm{~cm} \times 50 \mathrm{~cm}$ & $7.40 \mathrm{~b}$ & 23.67 & 46.57 & $65.17 \mathrm{a}$ & $67.43 \mathrm{a}$ \\
\hline $60 \mathrm{~cm} \times 60 \mathrm{~cm}$ & $7.83 \mathrm{~b}$ & 23.70 & 43.68 & $62.97 \mathrm{ab}$ & $66.23 \mathrm{a}$ \\
\hline \multicolumn{6}{|l|}{ Frekuensi pembumbunan } \\
\hline Dua kali & 8.04 & 21.69 & 40.90 & 56.70 & 60.30 \\
\hline Tiga kali & 8.64 & 23.55 & 44.68 & 57.79 & 61.26 \\
\hline
\end{tabular}

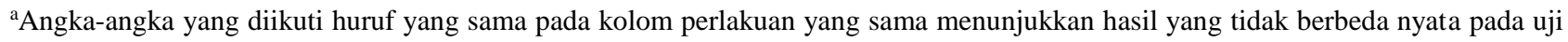
BNT taraf 5\%

Pertambahan jumlah daun pada 10 dan 12 MST semakin sedikit. Pada minggu-minggu tersebut tanaman kacang bogor sudah dimulai memasuki fase generatif. Hasil fotosintesis berupa karbohidrat yang pada awal pertumbuhan hanya digunakan untuk mendukung pertumbuhan vegetatif tanaman, pada fase generatif karbohidrat tersebut juga disalurkan untuk pembentukan dan pengisian polong tanaman. Hal ini sesuai dengan hasil penelitian Sobariah (1999) yang berpendapat pada tanaman sorgum yang sudah memasuki fase generatif, yang secara fisiologis ditandai dengan munculnya bunga pada sebagian populasi dengan demikian tidak seluruh karbohidrat digunakan untuk pertumbuhan vegetatif karena sebagian karbohidrat digunakan untuk pertumbuhan generatif. 
Lebar kanopi. Panjang tajuk diukur searah dengan arah barisan tanaman dan lebar kanopi diukur tegak lurus dengan arah barisan tanaman. Perlakuan jarak tanam memberikan pengaruh nyata pada peubah lebar kanopi pada 8,10 dan 12
MST. Rata-rata lebar kanopi pada tanaman dengan jarak tanam $50 \mathrm{~cm}$ x $50 \mathrm{~cm}$ dan $60 \mathrm{~cm} \times$ $60 \mathrm{~cm}$ nyata lebih lebar daripada jarak tanam lain (Tabel 3).

Tabel 3. Lebar kanopi kacang bogor pada beberapa jarak tanam dan frekuensi pembumbunan

\begin{tabular}{|c|c|c|c|c|c|}
\hline \multirow{2}{*}{ Perlakuan } & \multicolumn{5}{|c|}{ Umur tanaman (MST) } \\
\hline & $4 \mathrm{MST}$ & $6 \mathrm{MST}$ & $8 \mathrm{MST}$ & $10 \mathrm{MST}$ & $12 \mathrm{MST}$ \\
\hline Jarak tanam & \multicolumn{5}{|c|}{----------------cmª } \\
\hline $40 \mathrm{~cm} \times 25 \mathrm{~cm}$ & 29.70 & 44.37 & $51.52 \mathrm{~cd}$ & $54.42 \mathrm{~b}$ & $57.08 \mathrm{~b}$ \\
\hline $50 \mathrm{~cm} \times 25 \mathrm{~cm}$ & 29.90 & 43.67 & $50.83 \mathrm{~cd}$ & $55.23 \mathrm{~b}$ & $57.70 \mathrm{~b}$ \\
\hline $60 \mathrm{~cm} \times 25 \mathrm{~cm}$ & 32.15 & 45.07 & $50.07 \mathrm{~d}$ & $55.05 \mathrm{~b}$ & $57.58 \mathrm{~b}$ \\
\hline $40 \mathrm{~cm} \mathrm{x} 40 \mathrm{~cm}$ & 29.33 & 42.98 & $53.90 \mathrm{abc}$ & $56.55 \mathrm{~b}$ & $59.40 \mathrm{~b}$ \\
\hline $50 \mathrm{~cm} \mathrm{x} 50 \mathrm{~cm}$ & 29.75 & 46.32 & $55.22 \mathrm{a}$ & $60.92 \mathrm{a}$ & $63.53 \mathrm{a}$ \\
\hline $60 \mathrm{~cm} \times 60 \mathrm{~cm}$ & 28.05 & 45.15 & $55.05 \mathrm{ab}$ & $62.02 \mathrm{a}$ & $63.99 \mathrm{a}$ \\
\hline \multicolumn{6}{|l|}{ Frekuensi pembumbunan } \\
\hline Dua kali & 30.14 & 44.72 & 52.88 & 56.80 & 59.13 \\
\hline Tiga kali & 29.28 & 44.46 & 52.64 & 57.93 & 60.63 \\
\hline
\end{tabular}

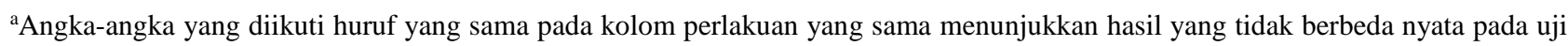
BNT taraf 5\%

Menurut Juwita (2012) lebar kanopi berkorelasi positif dengan bobot polong basah, bobot polong kering dan jumlah polong bernas, sehingga semakin besar lebar kanopi tanaman kacang bogor akan menghasil bobot polong yang semakin tinggi pula. Selain itu Actaria (2012) juga menyatakan tanaman dengan lebar kanopi yang besar memiliki jumlah cabang dan buku yang merupakan tempat munculnya polong yang besar pula, sehingga jumlah polong akan lebih banyak.

Indeks luas daun (ILD). Pengamatan indeks luas daun dilakukan satu kali selama penelitian berlangsung pada saat tanaman belum berbunga, yaitu umur 5 MST. Pengukuran dilakukan menggunakan alat bantu leaf area meter LI-3000C. Jarak tanam berpengaruh nyata terhadap peubah indeks luas daun. Berdasarkan Tabel 4 tanaman dengan jarak tanam $40 \mathrm{~cm} \times 25$ $\mathrm{cm}$ memiliki indeks luas daun terbesar dan berbeda nyata dengan jarak tanam lain. Suryadi et al. (2013) menyatakan bahwa pada kerapatan tanaman yang lebih tinggi, jumlah tanaman per satuan luas semakin banyak dan tajuk antar tanaman saling menutupi satu sama lain dalam usaha untuk mendapatkan cahaya matahari sehingga akan menghasilkan indeks luas daun yang besar.

Daun memiliki peranan penting sebagai tempat berlangsungnya fotosintesis dalam tanaman. Indeks luas daun merupakan perbandingan antara satu sisi luas daun terhadap luas lahan ternaungi yang merupakan jarak tanam. Indeks luas daun menggambarkan nilai luasan daun tertentu yang digunakan untuk fotosintesis. (Juliarina, 2012).
Tabel 4. Indeks luas daun kacang bogor pada beberapa jarak tanam dan frekuensi pembumbunan

\begin{tabular}{cc}
\hline Perlakuan & Indeks luas daun $^{\mathrm{a}}$ \\
\hline Jarak tanam & $0.39 \mathrm{a}$ \\
$40 \mathrm{~cm} \times 25 \mathrm{~cm}$ & $0.27 \mathrm{~b}$ \\
$50 \mathrm{~cm} \times 25 \mathrm{~cm}$ & $0.22 \mathrm{bc}$ \\
$60 \mathrm{~cm} \times 25 \mathrm{~cm}$ & $0.17 \mathrm{~cd}$ \\
$40 \mathrm{~cm}$ x $40 \mathrm{~cm}$ & $0.18 \mathrm{~cd}$ \\
$50 \mathrm{~cm} \times 50 \mathrm{~cm}$ & $0.11 \mathrm{~d}$ \\
$60 \mathrm{~cm} \times 60 \mathrm{~cm}$ & \\
Frekuensi pembumbunan & 0.23 \\
Dua kali & 0.22 \\
Tiga kali & \\
\hline angka-angka yang diikuti huruf yang sama pada kolom \\
perlakuan yang sama menunjukkan hasil yang tidak berbeda \\
nyata pada uji BNT taraf 5\%
\end{tabular}

Indeks luas daun erat kaitannya dengan populasi tanaman, luas daun, dan jumlah daun, karena indeks luas daun merupakan luas total daun per unit luas lahan. Semakin rapat tanaman semakin besar indeks luas daunnya dan semakin dikurangi daunnya (dipangkas) semakin berkurang indeks luas daunnya (Asyiardi dan Nurnayetti, 1995).

\section{Fase Generatif}

Fase generatif tanaman kacang bogor dimulai saat tanaman mulai berbunga yaitu pada 6 MST. Bunga kacang bogor berwarna kuning dan tumbuh dari ruas-ruas batang yang tumbuh menjalar.

Bobot brangkasan dan polong per tanaman. Bobot brangkasan kering per tanaman 
terbesar dimiliki oleh tanaman dengan jarak tanam $60 \mathrm{~cm} \times 60 \mathrm{~cm}$, tidak berbeda nyata dengan tanaman dengan jarak tanam $60 \mathrm{~cm} \times 25 \mathrm{~cm}$ dan $40 \mathrm{~cm} \times 40 \mathrm{~cm}$, namun berbeda nyata dengan tanaman dengan jarak tanam lain. Hasil analisis juga menunjukkan tiga kali pembumbunan menghasilkan bobot brangkasan kering per tanaman yang lebih besar daripada dua kali pembumbunan. Selain itu dapat dilihat bahwa semakin besar jarak antarbaris akan menghasilkan bobot brangkasan kering lebih besar (Tabel 5).

Tabel 5. Bobot brangkasan kering, bobot polong basah, bobot polong kering, dan bobot biji per tanaman kacang bogor

\begin{tabular}{|c|c|c|c|c|}
\hline \multirow{2}{*}{ Perlakuan } & \multicolumn{4}{|c|}{ Peubah } \\
\hline & $\mathrm{BBK}^{\mathrm{a}}$ & $\mathrm{BPB}^{\mathrm{a}}$ & $\mathrm{BPK}^{\mathrm{a}}$ & $\mathrm{BBJ}^{\mathrm{a}}$ \\
\hline Jarak tanam & \multicolumn{4}{|c|}{---------------gram--------------- } \\
\hline $40 \mathrm{~cm} \times 25 \mathrm{~cm}$ & $21.99 \mathrm{c}$ & $95.00 \mathrm{c}$ & $25.63 \mathrm{~d}$ & $17.00 \mathrm{~d}$ \\
\hline $50 \mathrm{~cm} \times 25 \mathrm{~cm}$ & $27.40 \mathrm{bc}$ & $108.75 \mathrm{bc}$ & $33.31 \mathrm{~cd}$ & $22.06 \mathrm{~cd}$ \\
\hline $60 \mathrm{~cm} \times 25 \mathrm{~cm}$ & $32.73 \mathrm{ab}$ & $128.33 \mathrm{bc}$ & $46.67 \mathrm{bc}$ & $27.62 \mathrm{bc}$ \\
\hline $40 \mathrm{~cm} \times 40 \mathrm{~cm}$ & $37.52 \mathrm{ab}$ & $101.67 \mathrm{bc}$ & $34.68 \mathrm{~cd}$ & $23.16 \mathrm{~cd}$ \\
\hline $50 \mathrm{~cm} \times 50 \mathrm{~cm}$ & $27.80 \mathrm{bc}$ & $154.33 \mathrm{ab}$ & $49.49 \mathrm{~b}$ & $35.19 \mathrm{~b}$ \\
\hline $60 \mathrm{~cm} \times 60 \mathrm{~cm}$ & $41.09 \mathrm{a}$ & $184.50 \mathrm{a}$ & $78.07 \mathrm{a}$ & $50.66 \mathrm{a}$ \\
\hline \multicolumn{5}{|l|}{ Frekuensi pembumbunan } \\
\hline Dua kali & $26.90 \mathrm{~b}$ & 128.94 & 42.22 & 27.89 \\
\hline Tiga kali & $35.94 \mathrm{a}$ & 128.58 & 47.07 & 30.67 \\
\hline
\end{tabular}

${ }^{a}$ Angka-angka yang diikuti huruf yang sama pada kolom perlakuan yang sama menunjukkan hasil yang tidak berbeda nyata pada uji $\mathrm{BNT}$ taraf $5 \%, \mathrm{BBK}=$ Bobot brangkasan, $\mathrm{BPB}=$ bobot polong basah, $\mathrm{BPK}=$ bobot polong kering, $\mathrm{BBJ}=$ bobot biji

Jarak tanam lebar memungkinkan akar tanaman dapat tumbuh dengan leluasa tanpa terhalang akar lain. Hal ini sesuai dengan pendapat Muliasari (2009) yang menyatakan jarak tanam yang lebar memungkinkan akar tanaman tersebut menjangkau lebih jauh untuk memperoleh unsur hara dan air dalam tanah, akibatnya pertumbuhan akar lebih baik dengan jarak tanam yang lebih lebar dibandingkan jarak yang lebih rapat. Hal ini menyebabkan bobot brangkasan yang dihasilkan tanaman dengan jarak tanam $60 \mathrm{~cm}$ x $60 \mathrm{~cm}$ paling besar.

Bobot polong basah dan kering, serta bobot biji tanaman jarak tanam $60 \mathrm{~cm} \times 60 \mathrm{~cm}$ memiliki bobot yang nyata paling besar dibandingkan dengan tanaman dengan jarak tanam lain. Daun-daun yang tumbuh pada tanaman dengan jarak tanam $60 \mathrm{~cm}$ x $60 \mathrm{~cm}$ tidak saling menutupi, sehingga lebih efektif menyerap cahaya matahari untuk proses fotosintesis Menurut Salisbury dan Ross (1995) pada tanaman yang mendapat cahaya yang lebih banyak, maka intensitas cahaya yang diterima akan lebih tinggi dan akibatnya proses foto-sintesis akan berjalan lebih cepat, sehingga suplai karbohidrat akan bertambah.

Pertumbuhan tanaman pada jarak tanam $60 \mathrm{~cm} \times 60 \mathrm{~cm}$ tumbuh dengan kompetisi atau persaingan yang lebih sedikit dibandingkan dengan tanaman yang ditanam dengan jarak tanam yang lebih rapat. Hal ini sejalan dengan pendapat Harjadi (1996) yang menyatakan bahwa adanya persaingan yang intensif diantara tanaman akan mengakibatkan terjadinya perubahan morfologi pada tanaman, seperti sejumlah organ yang terbentuk berkurang sehingga berdampak kurang baik terhadap perkembangan dan hasil tanaman.

Jumlah polong bernas, hijau, dan cipo per tanaman serta indeks panen. Hasil analisis menunjukkan bahwa jumlah polong bernas terbanyak ada pada tanaman dengan jarak tanam $60 \mathrm{~cm} \times 60 \mathrm{~cm}$ yang berbeda nyata dengan perlakuan lain (Tabel 6). Seperti pada peubah bobot jarak tanam juga memperngaruhi jumlah polong bernas pada kacang bogor. Kari et al. (1993) menyatakan bahwa jumlah polong per tanaman yang berubah berdasarkan jarak tanam karena adanya persaingan dalam pengambilan zat hara dan cahaya.

Polong cipo merupakan polong yang tidak berbiji atau hampa, sedangkan polong hijau merupakan polong yang tidak tertimbun tanah sehingga berwarna hijau. Polong cipo yang dihasilkan pada penelitian ini tidak banyak. Hal ini dikarenakan waktu panen yang tepat. Menurut Atifach (1992) sifat pembentukan polong pada kacang bogor pada buku-buku terujung/ terluar terus berlangsung selama pertumbuhannya. Polong yang terakhir terbentuk akan banyak yang belum terisi, sementara polong-polong yang terbentuk terlebih dahulu dan berada di dekat pangkal cabang telah mencapai kematangannya dan siap untuk dipanen. 
Tabel 6. Jumlah polong bernas (JPB), jumlah polong cipo (JPC), jumlah polong hijau (JPH), dan indeks panen (IP) per tanaman kacang bogor

\begin{tabular}{lcccc}
\hline & Perlakuan & \multicolumn{3}{c}{ Peubah } \\
\cline { 2 - 5 } & JPB $^{\text {a }}$ & JPC & JPH & IP \\
\hline Jarak tanam & & & & \\
$40 \mathrm{~cm} \times 25 \mathrm{~cm}$ & $20.9 \mathrm{~d}$ & 0.7 & 1.5 & 0.53 \\
$50 \mathrm{~cm} \times 25 \mathrm{~cm}$ & $30.7 \mathrm{~cd}$ & 0.7 & 0.9 & 0.56 \\
$60 \mathrm{~cm} \times 25 \mathrm{~cm}$ & $23.9 \mathrm{~cd}$ & 0.9 & 0.9 & 0.58 \\
$40 \mathrm{~cm} \times 40 \mathrm{~cm}$ & $38.1 \mathrm{~b}$ & 0.3 & 3.6 & 0.49 \\
$50 \mathrm{~cm} \times 50 \mathrm{~cm}$ & $49.9 \mathrm{a}$ & 1.1 & 1.5 & 0.62 \\
$60 \mathrm{~cm} \times 60 \mathrm{~cm}$ & & & & 0.65 \\
Frekuensi pembumbunan & 29.8 & 0.6 & 1.5 & 0.59 \\
Dua kali & 33.0 & 0.9 & 1.5 & 0.56 \\
Tiga kali & & & \\
\hline
\end{tabular}

${ }^{a}$ Angka-angka yang diikuti huruf yang sama pada kolom perlakuan yang sama menunjukkan hasil yang tidak berbeda nyata pada uji BNT taraf 5\%

Polong pada tanaman kacang tanah terbentuk di dalam tanah karena ginofornya panjang dan masuk ke dalam tanah setelah terjadi proses pembuahan. Sedangkan tanaman kacang bogor, ginofor lebih pendek sehingga polong yang di permukaan tanah berwarna hijau. Polong berwarna hijau sangat disukai tikus. Tindakan pembumbunan dengan menggemburkan tanah di sekitar tanaman dan menutup polong agar cepat masak sangat diperlukan (Redjeki, 2007). Hasil analisis menunjukkan bahwa jarak tanam dan frekuensi pembumbunan tidak berpengaruh nyata terhadap jumlah polong hijau.

Perhitungan indeks panen menunjukkan pembagian bahan kering oleh tanaman pada hasil panen biologis dan hasil panen ekonomis. Indeks panen tinggi menunjukan bahwa semakin banyak asimilat yang disalurkan ke bagian ekonomis (Juliarina, 2012). Namun Tabel 6 menunjukkan jarak tanam tidak berpengaruh nyata pada indeks panen dan dapat dilihat terdapat kecenderungan semakin besar jarak antarbaris akan menghasilkan indeks panen yang lebih besar.

Produksi. Pengamatan bobot polong basah dilakukan dengan menimbang seluruh polong dari satu petak perlakuan lalu mengkoversinya ke dalam satuan hektar. Tabel 7 menunjukkan tanaman dengan jarak tanam $50 \mathrm{~cm} \times 25 \mathrm{~cm}$ memiliki bobot polong basah terbesar dan hanya berbeda nyata dengan tanaman dengan jarak tanam $60 \mathrm{~cm} \times 60 \mathrm{~cm}$.

Tabel 7. Produksi kacang bogor

\begin{tabular}{|c|c|c|c|}
\hline \multirow{2}{*}{ Perlakuan } & \multicolumn{3}{|c|}{ Peubah } \\
\hline & Bobot polong basah $^{\mathrm{a}}$ & Bobot polong kering $^{\mathrm{a}}$ & Bobot biji $^{\mathrm{a}}$ \\
\hline Jarak tanam & \multicolumn{3}{|c|}{------------------------ton ha'-1---------------------- } \\
\hline $40 \mathrm{~cm} \times 25 \mathrm{~cm}$ & $5.90 \mathrm{a}$ & $1.72 \mathrm{ab}$ & $1.15 \mathrm{a}$ \\
\hline $50 \mathrm{~cm} \times 25 \mathrm{~cm}$ & $5.96 \mathrm{a}$ & $1.84 \mathrm{ab}$ & $1.19 \mathrm{a}$ \\
\hline $60 \mathrm{~cm} \times 25 \mathrm{~cm}$ & $5.64 \mathrm{a}$ & $2.04 \mathrm{a}$ & $1.23 \mathrm{a}$ \\
\hline $40 \mathrm{~cm} \mathrm{x} 40 \mathrm{~cm}$ & $5.69 \mathrm{a}$ & $1.95 \mathrm{ab}$ & $1.29 \mathrm{a}$ \\
\hline $50 \mathrm{~cm} \times 50 \mathrm{~cm}$ & $5.20 \mathrm{a}$ & $1.52 \mathrm{bc}$ & $1.06 \mathrm{a}$ \\
\hline $60 \mathrm{~cm} \times 60 \mathrm{~cm}$ & $3.15 \mathrm{~b}$ & $1.13 \mathrm{c}$ & $0.74 \mathrm{~b}$ \\
\hline \multicolumn{4}{|l|}{ Frekuensi pembumbunan } \\
\hline Dua kali & 5.33 & 1.68 & 1.10 \\
\hline Tiga kali & 5.19 & 1.72 & 1.12 \\
\hline
\end{tabular}

Berdasarkan analisis data diketahui bahwa tanaman yang diberi jarak tanam sebesar $60 \mathrm{~cm} \mathrm{x}$ $25 \mathrm{~cm}$ memiliki bobot polong kering lebih besar daripada tanaman dengan jarak tanam sebesar 50 $\mathrm{cm} \times 50 \mathrm{~cm}$ dan $60 \mathrm{~cm} \times 60 \mathrm{~cm}$. Bobot biji terbesar dihasilkan dari tanaman dengan jarak tanam $40 \mathrm{~cm} \times 40 \mathrm{~cm}$ dan hanya berbeda dengan jarak tanam $60 \mathrm{~cm}$ x $60 \mathrm{~cm}$ (Tabel 7).

Perlakuan frekuensi pembumbunan yang digunakan hampir tidak berpengaruh untuk semua peubah kecuali pada peubah bobot brangkasan kering. Hal ini diduga karena frekuensi yang digunakan kurang intensif, selain itu juga bisa dikarenakan waktu dilakukan pembumbunan kurang tepat.

\section{Uji Korelasi Antar Karakter}

Hubungan antara satu karakter dengan karakter lainnya perlu diketahui. Karakter bobot 
polong dan jumlah polong bernas merupakan karakter produksi yang diharapkan akan baik hasilnya dalam penelitian ini (Juwita, 2012). Karakter bobot polong dan jumlah polong bernas ini sulit diamati di lapang ketika tanaman belum dipanen. Maka dari itu perlu diketahui karakter fenotip yang berkorelasi dengan karakter bobot polong tersebut.

Lampiran 1 menunjukkan bahwa karakter jumlah daun nyata berkorelasi positif dengan lebar kanopi. Meskipun dalam penelitian ini tidak ditemukan korelasi antara karakter jumlah daun, lebar kanopi, jumlah polong, dan bobot polong, namun pada penelitian sebelumnya telah diketahui bahwa jumlah daun dan lebar kanopi berkorelasi positif dengan karakter jumlah dan bobot polong (Damayanti 1991; Atifach 1992; Actaria 2012; Juwita, 2012).

Karakter indeks luas daun berkorelasi negatif dengan bobot polong basah dan bobot biji per tanaman. Hal tersebut terjadi karena pada indeks luas daun yang besar kerapatan tanaman juga akan semakin tinggi dan pada kerapatan tanaman yang tinggi kompetisi yang terjadi pada tanaman akan semakin tinggi pula yang kemudian akan menghasilkan bobot polong basah dan bobot biji per tanaman yang rendah. Bobot brangkasan kering per tanaman berkorelasi positif dengan bobot polong basah dan jumlah polong hijau per tanaman. Hal tersebut menunjukkan bahwa semakin banyak fotosintat yang diakumulasikan di bagian atas tanaman semakin banyak pula yang diangkut ke polong (Lampiran 1). Kasno et al. (1983) menyatakan adanya korelasi positif antara bobot brangkasan basah per tanaman dengan hasil pada kacang tanah.

Bobot polong basah dan jumlah polong bernas per tanaman berkorelasi negatif dengan bobot polong basah dan kering serta bobot biji petakan. Keadaan ini berkaitan kembali dengan jarak tanam yang digunakan. Bobot polong kering per tanaman berkorelasi positif dengan bobot biji per tanaman dan jumlah polong bernas per tanaman. Hal ini berarti semakin banyak jumlah polong bernas pada tanaman, akan semakin besar bobot polong kering dan bobot bijinya. Bobot polong basah petakan berkorelasi positif dengan bobot polong kering dan bobot biji petakan. Bobot polong kering petakan berkorelasi positif dengan bobot biji petakan. Hal ini berarti semakin besar bobot polong basah dan kering petakan akan semakin besar pula bobot biji yang dihasilkan. Elia (1985) menyatakan bahwa jumlah polong dan jumlah cabang per tanaman merupakan komponen hasil yang penting pada kacang bogor.

\section{KESIMPULAN}

Jarak tanam $60 \mathrm{~cm} \times 60 \mathrm{~cm}$ memberikan potensi pertumbuhan dan hasil yang paling baik jika dilihat dari tiap individu tanaman. Jarak tanam $60 \mathrm{~cm} \times 25 \mathrm{~cm}$ dan $40 \mathrm{~cm} \times 40 \mathrm{~cm}$ memberikan pertumbuhan dan produksi yang paling baik dibandingkan jarak tanam lain. Frekuensi pembumbunan yang digunakan belum memberikan pengaruh pada peubah-peubah yang diamati.

\section{DAFTAR PUSTAKA}

Actaria, D. 2012. Evaluasi galur-galur kacang bogor (Vigna subterranea (L.) Verdcourt) asal Sukabumi [skripsi]. Bogor (ID): Institut Pertanian Bogor.

Asyiardi, Nurnayetti. 1995. Pengaruh jarak barian tanam dan pemangkasan daun bawah tanaman jagung dalam tumpangsari dengan kacang tanah terhadap efisiensi radiasi surya dan produksi. Risalah Seminar Balittan Sukarami. 8:104-115.

Atifach, A. 1992. Pengaruh pemberian pupuk kandang dan fosfor terhadap pertumbuhan dan hasil kacang bogor (Vigna subterranea (L.) Vercourt) [skripsi]. Bogor (ID): Institut Pertanian Bogor.

Baudoin, J.P, Mergeai, G. 2001. Grain Legumes in Crop Production in Tropical Africa. Accra (GN).

Brink, M., Ramolemana, G.M., Sibuga, K.P. 2006. In: Brink M, Belay G, editors. Vigna subterranea (L.) Verdcourt. Plant Resources of Tropical African Cereals and Pulses; Wagenigen, Netherlands. Wagenigen (NL): PROTA Foundat.

Damayanti, A. 1991. Pengaruh pemiloahan warna benih terhadap hasil dan komponen hasil (Vigna subterranea (L.) Verdcourt) [skripsi]. Bogor (ID): Institut Pertanian Bogor.

Deshpande, S.S., Damodaran, S. 1990. Food legumes: chemistry and technology. $A d v$ Cer Sci Tech. (10):147-241. 
Elia, F.M. 1985. Variability for yield and seed yield components in Bambara groundnut (Voandzeia subterranea Thoars). Trop. Grain Legume Bull. 31:39-44.

Harjadi, S.S. 1991. Pengantar Agronomi. Jakarta (ID): PT. Gramedia.

Hasanuddin, Bahri, L., Adrizal. 1999. Analisis pertumbuhan tanaman kedelai pada berbagai varietas, jarak tanam dan pemupukan. Agrista. 3(1):47-52.

Juliarina N.W.S. 2012. Kapasitas fotosintesis 5 varietas kacang tanah dalam hubungannya dengan produktivitas [skripsi]. Bogor (ID): Institut Pertanian Bogor.

Juwita, L. 2012. Pembentukan populasi dasar untuk perbaikan produksi kacang bogor (Vigna subterranea (L.) verdcourt) asal Dramaga, Sukabumi, dan Parung [skripsi]. Bogor (ID): Institut Pertanian Bogor.

Kasno, A., Bari, A., Mattjik, A.A., Solahuddin, S., Somaatmadja, S., Subandi. 1987. Telaah interaksi genotipe $x$ lingkungan pada kacang tanah, 1. Pendugaan parameter genetik hasil dan komponen hasil kacang tanah (Arachis hypogea (L.) Merr). Penelitian Palawija. 2(2):81-88.

Muliasari, A.A. 2009. Optimasi jarak tanam dan umur bibit pada padi sawah (Oryza sativa L.) [Skripsi]. Bogor (ID): Institut Pertanian Bogor.

Purseglove, J.W. 1992. Tropical Crops (Dicotyledons). London (GB): Longman.

Redjeki, E.S. 2007. Pertumbuhan dan hasil tanaman kacang bogor (Vigna subterranea
(L.) Verdcourt) galur Gresik dan Bogor pada berbagai jenis biji. Seminar Nasional Hasil Penelitian yang Dibiayai oleh Hibah Kompetitif [internet]; 2007 Agustus 1-2; Bogor Indonesia. Bogor (ID): Fakultas Pertanian Universitas Muhammadiyah Gresik. Hlm 114-118; [diunduh 2013 Sept 10]. Tersedia pada: http://www.agrohort. ipb.ac.id/downloads/Prosiding

Salisbury, F.B., Ross, C.W. 1995. Fisiologi Tumbuhan. Jilid II. Lukman DR, Sumaryono, penerjemah. Bandung (ID): ITB Bandung. Terjemahan dari: Plant Phisiology.

Sobariah, L. 1999. Uji adaptasi dan pengaruh jarak tanam terhadap sorgum manis (Sorghum bicolor (L.) Moench) varietas RIO, RGV, dan Cowley pada lahan kering iklim basah [skripsi]. Bogor (ID): Institut Pertanian Bogor.

Suryadi, Setyobudi, L., Soelistyono. 2013. Kajian intersepsi cahaya matahari pada kacang tanah (Arachis hypogaea L.) diantara tanaman melinjo menggunakan jarak tanam berbeda. Jurnal Produksi Tanaman 1(4):4250 .

Turmudi, E., Gonggo, B., Irwan, M. 1996. Keragaan jagung manis pada berbagai kerapatan tanaman dalam sistem tumpang sari dengan cabe merah [catatan penelitian]. Penelitian UNIB. (7):14-18.

Turmudi, E., Suprijono, E. 2004. Pertumbuhan dan hasil tanaman kacang bogor pada berbagai tingkat kerapatan tanaman dan frekuensi penyiangan [catatan penelitian]. Penelitian UNIB. 


\section{Bul. Agrohorti 4 (3): 302-311 (2016)}

Lampiran 1. Koefisien korelasi antar karakter tanaman kacang bogor

\begin{tabular}{|c|c|c|c|c|c|c|c|c|c|c|c|c|c|c|c|c|c|c|c|}
\hline Karakter $^{\mathrm{a}}$ & JD 4 & JD 6 & JD 10 & JD 12 & LK 6 & LK 8 & LK 10 & LK 12 & ILD & BBK & BPB & BPK & BBJ & JPB & JPC & JPH & IP & BPBP & BPKP \\
\hline JD 6 & 0.14 & & & & & & & & & & & & & & & & & & \\
\hline JD 10 & $-0.81 *$ & 0.46 & & & & & & & & & & & & & & & & & \\
\hline JD 12 & -0.76 & 0.53 & $0.99 * *$ & & & & & & & & & & & & & & & & \\
\hline LK 6 & -0.15 & $0.92 *$ & 0.66 & 0.71 & & & & & & & & & & & & & & & \\
\hline LK 8 & -0.95 & 0.10 & $0.92 *$ & $0.89 *$ & 0.34 & & & & & & & & & & & & & & \\
\hline LK 10 & -0.75 & 0.49 & $0.97 * *$ & $0.96 * *$ & 0.59 & $0.89 *$ & & & & & & & & & & & & & \\
\hline LK 12 & -0.79 & 0.46 & $0.98 * *$ & $0.97 * *$ & 0.59 & $0.91 *$ & $0.99 * *$ & & & & & & & & & & & & \\
\hline ILD & 0.55 & -0.22 & -0.66 & -0.60 & -0.23 & -0.65 & -0.77 & 0.77 & & & & & & & & & & & \\
\hline BBK & -0.53 & 0.16 & 0.59 & 0.59 & 0.07 & 0.67 & 0.75 & -0.72 & -0.74 & & & & & & & & & & \\
\hline BPB & -0.37 & -0.17 & 0.46 & 0.42 & -0.19 & 0.65 & 0.61 & 0.60 & $-0.84 *$ & $0.89 *$ & & & & & & & & & \\
\hline BPK & -0.59 & -0.78 & -0.11 & -0.21 & -0.71 & 0.13 & -0.09 & -0.07 & -0.21 & 0.12 & 0.43 & & & & & & & & \\
\hline BBJ & -0.44 & $-0.61 *$ & 0.06 & -0.01 & -0.63 & 0.41 & 0.18 & 0.17 & $-0.45^{*}$ & 0.53 & 0.73 & $0.89 *$ & & & & & & & \\
\hline JPB & 0.47 & -0.62 & 0.17 & 0.09 & -0.57 & -0.51 & 0.24 & 0.25 & -0.44 & 0.48 & 0.69 & $0.92 * *$ & $0.98 * *$ & & & & & & \\
\hline JPC & 0.44 & 0.28 & -0.24 & -0.22 & 0.13 & 0.29 & -0.21 & -0.25 & 0.26 & -0.33 & -0.47 & 0.06 & -0.04 & -0.08 & & & & & \\
\hline JPH & -0.23 & 0.07 & 0.25 & 0.29 & -0.13 & 0.35 & 0.44 & 0.39 & -0.32 & $0.86^{*}$ & 0.64 & 0.06 & 0.47 & 0.38 & -0.15 & & & & \\
\hline IP & 0.01 & -0.70 & -0.42 & -0.49 & -0.63 & -0.31 & -0.48 & -0.45 & 0.29 & -0.43 & -0.18 & 0.80 & 0.52 & 0.56 & 0.43 & -0.33 & & & \\
\hline BPBP & -0.58 & 0.39 & -0.21 & -0.15 & 0.46 & -0.39 & -0.47 & -0.35 & 0.63 & -0.70 & $-0.85^{*}$ & -0.77 & $-0.96^{* *}$ & $-0.92 * *$ & 0.05 & -0.59 & -0.31 & & \\
\hline BPKP & 0.54 & 0.33 & -0.31 & -0.25 & 0.37 & -0.47 & -0.45 & -0.44 & 0.67 & -0.72 & $-0.84 *$ & -0.75 & $-0.95 * *$ & $-0.92 * *$ & 0.02 & -0.57 & -0.29 & $0.99 * *$ & \\
\hline BBJP & 0.55 & 0.33 & -0.33 & -0.26 & 0.35 & -0.49 & -0.37 & -0.46 & 0.74 & -0.71 & $-0.88 *$ & -0.75 & $-0.93^{* *}$ & $-0.91 *$ & 0.09 & -0.52 & -0.27 & $0.99 * *$ & $0.99 * *$ \\
\hline
\end{tabular}

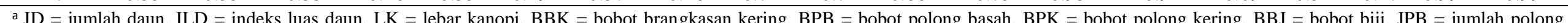

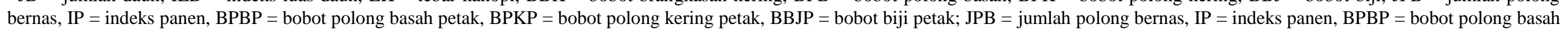
petak, $\mathrm{BPKP}=$ bobot polong kering petak, $\mathrm{BBJP}=$ bobot biji petak, $(4,6,8,10,12) \mathrm{MST} ; *=$ berkorelasi nyata pada taraf $5 \%$; $* *=$ berkorelasi nyata pada taraf $1 \%$ 